\title{
„A bántalmazás megelőzését a nyílt társadalmi kommunikáció segíti..."
}

\author{
„Child abuse can be prenvented by open social communication..."
}

doi: $\quad 10.24365 /$ ef.v60i1.431

Olvasói szavazás alapján „2018. legjobb cikke” a gyermekbántalmazás magyarországi helyzetét és a prevenciós munka fontosságát mutatja be. Rövid interjút készitettünk a közlemény első szerzőjével, Tománé Mészáros Andrea védőnővel. A teljes cikk itt olvasható: Hogyan előzzük meg a gyermekbántalmazást? A prevenciós munka jelentösége és kihivásai

Gratulálunk az olvasói szavazáson elért első helyezéséhez! Miért tartja cikke témáját fontosnak?

Nagyon köszönöm ezt az elismerést társszerzőim nevében is. Visszaigazolása annak, hogy beszélni kell a gyermekbántalmazás súlyos problémaköréről. Az Egészségfejlesztés folyóirat nagy múltú, a szakmai körökben elismert tudományos platform. Megtisztelö, hogy a cikkem megjelenhetett itt. Védőnőként, több mint 15 éve elköteleződtem a gyermekbántalmazás megelőzése mellett. Témámat fontosnak tartom, hisz a közbeszédben gyakran előkerül, de a tudományos életben nem kap nagy hangsúlyt. PhD hallgatóként remélem sikerül egy kicsit több figyelmet irányítani rá. A gyermekbántalmazás rendkívül szenzitív terület, ahol mély érzelmek, traumák temetődnek el hosszú időre, vagy kerülnek felszínre. Gyakori a szégyenérzet. A szakemberek sokszor kerülik a témát, félrenéznek, mert eszköztelenek. Ennek következtében a gyermekek tovább sérülnek. A bántalmazás transzgenerációs hatásai miatt rendkívül fontos lenne megállítani a bántalmazói kört és támogatni a gyermekeket egy boldogabb élet kialakításában.

A WHO a gyermekbántalmazást, annak hosszú távú hatásai miatt népegészségügyi problémává nyilvánította.

Hogyan foglalná össze üzenetét röviden a szakemberek, illetve a nagyközönség számára?

A legfontosabb üzenet, hogy a gyermekbántalmazás megelőzhető. Ehhez számos tényező szükséges.
Az alap a bántalmazás teljes elutasítása. A magyar jogszabályok jók, kimondják, hogy a gyermek mindenfajta bántalmazása tilos. Azonban a mindennapokban kevéssé tudják betartani mind a szülők, mind a szakemberek. Sokat segítene a bántalmazás megelőzésében az Isztambuli Egyezmény ratifikálása és az előirásainak beemelése a magyar jogrendbe. Számos szülő nehezen tud megbirkózni nevelési, gondozási feladataival. Nincsenek jó példák előttük, nem ismerik a pozitív szülői eszköztárat. A szakemberek feladata a támogatás, az oktatás, hogy minél jobb szülővé tudjanak válni. Ezzel párhuzamosan nagyon fontos a szakemberek ismereteinek további mélyítése, eszköztáruk bővítése.

Van-e személyes élménye mindezzel kapcsolatosan?

Körzeti védőnőként egy fővárosi peremkerületben dolgoztam. Számos elhanyagolási és bántalmazási esettel találkoztam. Jelzési kötelezettség már akkor is volt, meg is tettem a szükséges lépéseket. Azonban máig ható élmény a rendszer tehetetlensége és a saját frusztráltságom, amikor nem sikerült segíteni egy-egy gyermeken. Szerencsére ebben azért sok változás történt az elmúlt években. Nem állítom, hogy minden hibátlanul működik, de nagyon sok szakember lelkiismeretesen dolgozik azért, hogy jobb legyen a gyerekeknek. Mély meggyőződésem, hogy a bántalmazás megelőzését a nyílt társadalmi kommunikáció segíti. Továbbá az újonnan fókuszba került bántalmazási formák 
(pl. bullying, on-line bántalmazások, stb.) megelőzésében, kezelésében a szakmaközi együttmúködést tovább kell erősíteni.

\section{Gyakran publikál-e? Ezúttal miért az}

Egészségfejlesztés folyóiratot választotta?

Korábbi munkahelyemen, az Országos Gyermekegészségügyi Intézetben múködő munkacsoport tagjaként számos feladatban vettem részt, például szakmai irányelvek kidolgozásában, weboldal létrehozásában. Tudományos cikkek írásával csak az utóbbi 1,5 évben foglalkoztam. A gyermekbántalmazásnak van magyar nyelvű szakirodalma, azonban a saját kutatási területem, a „Shaken Baby Syndrome" (megrázott gyermek szindróma) magyar nyelvű irodalma meglehetősen szegényes. Így szándékaim szerint a további cikkek már erre a területre fognak irányulni. Védőnőként hiszem, hogy az egészségtudatos életmódhoz hozzátartozik a testi-lelki egyensúly, jóllét. Ennek megalapozása a biztonságos gyermekkor. Az „elég jó szülővé” válás tanulható, ezáltal a gyermekbántalmazás elkerülhető. Az Egészségfejlesztés folyóirat különszáma kiváló felület volt ennek a témának a megjelenítésére, amiért ezúton is köszönetet mondok.

\section{Mit javasol a publikálás előtt állóknak?}

Olvassák a hazai és külföldi szakirodalmat. Minél többet írjanak. És higgyenek abban, hogy ha szenvedéllyel és kellő tudással csinálnak valamit, az másoknak is hasznos lesz. 